\title{
Woodframe: light framing houses for developing countries
}

\section{Woodframe: viviendas de entramado ligero para países en desarrollo}

\author{
Victor Almeida De Araujo (Main Author) \\ Research Group of Development of Lignocellulosic Products - LIGNO \\ victor@usp.br / engim.victor@yahoo.de
}

Juliana Cortez-Barbosa (Contact Author)

State University of São Paulo - UNESP, Department of Wood Industrial Engineering

Geraldo Alckmin, 519, 18409-010, Itapeva-SP, Brazil. Phone: +55-15-35249100

jucortez@itapeva.unesp.br

José Nivaldo Garcia

University of São Paulo - USP-ESALQ, Department of Forest Sciences

jngarcia@usp.br

\section{Maristela Gava}

State University of São Paulo - UNESP, Department of Wood Industrial Engineering mgava@itapeva.unesp.br

\section{Christine Laroca}

Federal University of Technology of Paraná - UTFPR, Department of Civil Construction wood_arquitetura@hotmail.com.br

\section{Sandro Fábio César}

Federal University of Bahia - UFBA, Department of Construction and Structures sfcesarpaz@ufba.br

Manuscript Code: 564

Date of Acceptance/Reception: 01.08.2016/22.12.2014

\section{ABSTRACT}

The building technique of light wooden framing, i.e., woodframe, represents a great innovative goal of construction, due to the very efficient levels of rationalization of material, operational flexibility and productive agility. In addition, excessive use of natural materials of renewable character in the woodframes, as the wood of planted forests, contributes to sustainability, a desired factor in most modern homes. In recent years, Latin American countries have suffered from the constant housing deficit, which destroys the possibilities of the first property by the neediest populations. Therefore, it is necessary to propagate studies, research and information on industrialized housing construction techniques, such as woodframe. This study focused on the exhibition by a state of the art of this innovative wooden housing typology, emphasizing its advantages, importance, types, and its current panorama in the regions in development stage, such as Latin American countries. Currently, the woodframe is known as a modern wooden residential technique, and it is conquering the public of all kind of economic classes, because of its innovation, lightness, competitive costs, and also by the efficient levels of sustainability, cleanness, assembly time, and rationalization of raw materials.

Keywords: light framing, wooden housing, wood-frame, dissemination, strategies.

RESUMEN

La técnica de construcción de entramado ligero en madera, i.e., woodframe, representa un gran objetivo innovador, debido a los niveles muy eficientes de racionalización de material, flexibilidad de las operaciones, y agilidad productiva. Además, el uso excesivo de materiales naturales de carácter renovable en los entramados ligeros, como la madera de los bosques plantados, contribuye con la sostenibilidad, un factor deseado en la mayoría de las viviendas modernas. En los últimos años, los países latinoamericanos han sufrido el constante déficit de viviendas, lo que destruye las posibilidades de la primera propiedad de las poblaciones más necesitadas. Por lo tanto, es necesario propagar los estudios, la investigación y la información sobre las técnicas de construcción de viviendas industrializadas, como el entramado ligero en madera. Este estudio se centró en la exposición por un estado del arte de esta innovadora tipología de vivienda en madera, destacando sus ventajas, importancia, tipos y su panorama actual en las regiones en fase de desarrollo, como los países de América Latina. En la actualidad, lo entramado ligero en madera es conocido como una técnica de viviendas en madera moderna, y que está conquistando al público de todas las clases económicas, debido a su innovación, ligereza, costos competitivos, y también por los niveles eficientes de sostenibilidad, limpieza, tiempo de montaje y la racionalización de las materias primas. 
Timber is the oldest raw material applied in construction, because of its availability in nature and relative ease of handling (Pfeil and Pfeil, 2003). The absence of wood in its most usual forms would imply a very different civilization than current, insofar as wood was present in the ages of stone, iron and bronze, contributing to the advancement of humanity, largely because it is a renewable material (Junior and Dias, 1997).

Few building materials have environmental benefits offered by wood (Falk, 2010). Of all the conventional materials for construction, wood has a great relationship resistance / weight, and also it presents a great facility in the production of many manufactured objects, as well as it propitiates an efficient thermal insulation (Pfeil and Pfeil, 2003). Unlike metals and fossil-fuel-based products (plastics), our forest resource is renewable and with proper management a flow of wood products can be maintained indefinitely (Falk, 2010).

Szücs (2006) notes that reforested wood is a noble product, which it has many beneficial characteristics in its use as construction part or element, and it has favorable conditions to generate comfort for the users. In North America, most residential houses and commercial structures built prior to the 20th Century used the timber as the major structural material. Today, houses and many light commercial and industrial buildings are made using modern wooden structural raw materials (Wacker, 2010).

Cortez-Barbosa et al. (2014) summarize that "since the advent of the industrial revolution, numerous materials have been invented and combined to meet the needs of consumer society and, recently, to address increasing environmental concerns and requirements". Previously, the planks and the blocks of wood were exclusively applied in structures, walls, flooring, ceilings and roofs, whereas currently these applications can also made by wooden engineered products: panels and composites such as beams. The structural panels include Oriented Strand Boards (OSB) and plywood, i.e., boards made with thin wooden laminas in cross orientation, and glued with waterproof resins, such as formaldehyde-based.

Regarding to the structural composite lumber, they are wood-based beams formed by: glued laminated timber (Glulam), cross laminated timber (CLT), laminated strand lumber (LSL), parallel strand lumber (PSL), oriented strand lumber (OSL), parallel strand lumber (PSL), and laminated veneer lumber (LVL). These wooden beams could safely reach large spans wider than a conventional lumber stud. There are other timber beams as "I-joist" (flanges in LVL or solid wood with a web in LVL, OSB or plywood), flitch (steel-reinforced), and box (lumber sandwiched by two plywood pieces).

Moreover, prefabricated floor and wall panels along with prefabricated roof and floor trusses or I-joists are replacing piece-by-piece on-site construction with dimension lumber. A light wood structure can be enclosed within a short time on site using factory-made panelized systems (Wacker, 2010). Thus, these wood-based raw materials were developed to supply timber housing industry, particularly the prefabricated woodframes.

\section{Description of the problem}

This study is focused on the exhibition by a state of the art about woodframe, a modern wooden housing typology, which for decades has been a relevant and popular technique in developed nations from Europe, Oceania, and North America. The proposal of this paper is to elucidate technicians, engineers, teachers, researchers, students and workers of civil construction about the woodframe technique, emphasizing the main concepts, importance, types, advantages and its current situation of expansion in developing nations such as Latin American ones, especially Brazil. The article is based on a state of the art about this theme, with an exhibition of its characteristics and an implication of its possibilities and trends.

State of the art

\section{Woodframe Housing}

Wooden light framing is popularly known as woodframe, and it can also be found in other terms such as wood-frame or wood frame, or else by its usual codename, light woodframe. This building technique is still designated by wooden panel houses and panelized homes. In foreign languages, it could be designated as ossature légère en bois in French, entramado leve em madeira or sistema reticulado leve em madeira in Portuguese, entramado ligero in Spanish, 
ossatura leggera in legno in Italian, holzrahmenbauweise in German, lekki szkielet drewniany in Polish, houtskeletbouw in Dutch and lätt trästomme in Swedish.

As the main characteristic, woodframe uses small-dimension parts of reforested wood and double sandwiched walls, which use wood-based panels (Krüger and Laroca, 2009). The modern conventional wood-frame house, with wood or wood product covering materials, is economical, long lasting, and it can be built in any location (Anderson, 1975). The flexibility of woodframe is the result of numerous possibilities, in which these houses can be built. This amplitude includes single- or multi-family types, single- or multi-storey sizes, modern or traditional styles, elaborated or minimalist designs, and also high quality or popular standards of finish. In this latter issue, these residences could present from a compact low-cost model to a modern hi-tech example with home automation services.

The requirements for wall-framing lumber are good stiffness, nail-holding ability, free-warp parts, and ease of working (Anderson, 1975). In general, the woods used in woodframes are from planted or managed forests, in which include conifers species such as: pine, larch, fir, spruce, cedar, birch, cypress and hemlock. In addition to these, on a lesser extent, some varieties of angiosperms can also usually be used, such as eucalyptus, poplar, maple and oak. These woods can be structurally used, both in lumber and in engineered products (panels and beams). In this latter case, the engineered beams are applied to the framing - replacing the sawn wood - and the structural boards are commonly used in bearing wall.

Light wood-frame construction originated in United States over 150 years ago and quickly evolved into the predominant construction system for housing and other small-scale buildings. Today, over $90 \%$ of all new North American buildings are made using some version of this method (Thallon, 2008). Historically, two light-frame styles have been used: balloon and platform (Wacker, 2010). In other languages, balloonframe is known as ossature croisée in French, entramado balão in Portuguese, struttura a pallone in Italian, and sistema globo in Spanish.

Thus, platform frame is identified as ossature plate-forme in French, entramado plataforma in Portuguese, struttura intelaiata di legno in Italian and sistema plataforma con entramado ligero in Spanish. Balloon wooden framing was the first model of industrialized building (Benoit and Paradis, 2008). Balloon frame was created in 1830 in United States, and it consists in the technique of framing, which it requires long lumber length for two-story houses (O'Brien, 2010). This system uses studs to complete the total height of structure (Figure 1), between bottom plates and top joists (Ching, 2010). Balloon is in decline phase, because it does not allow prefabricated parts, due to its long studs (Durán, 2004). These studs are installed very close together (Benoit et al., 2008).

Figure 1. Assembly framing sequences of balloon and platform. (O'Brien, 2010).
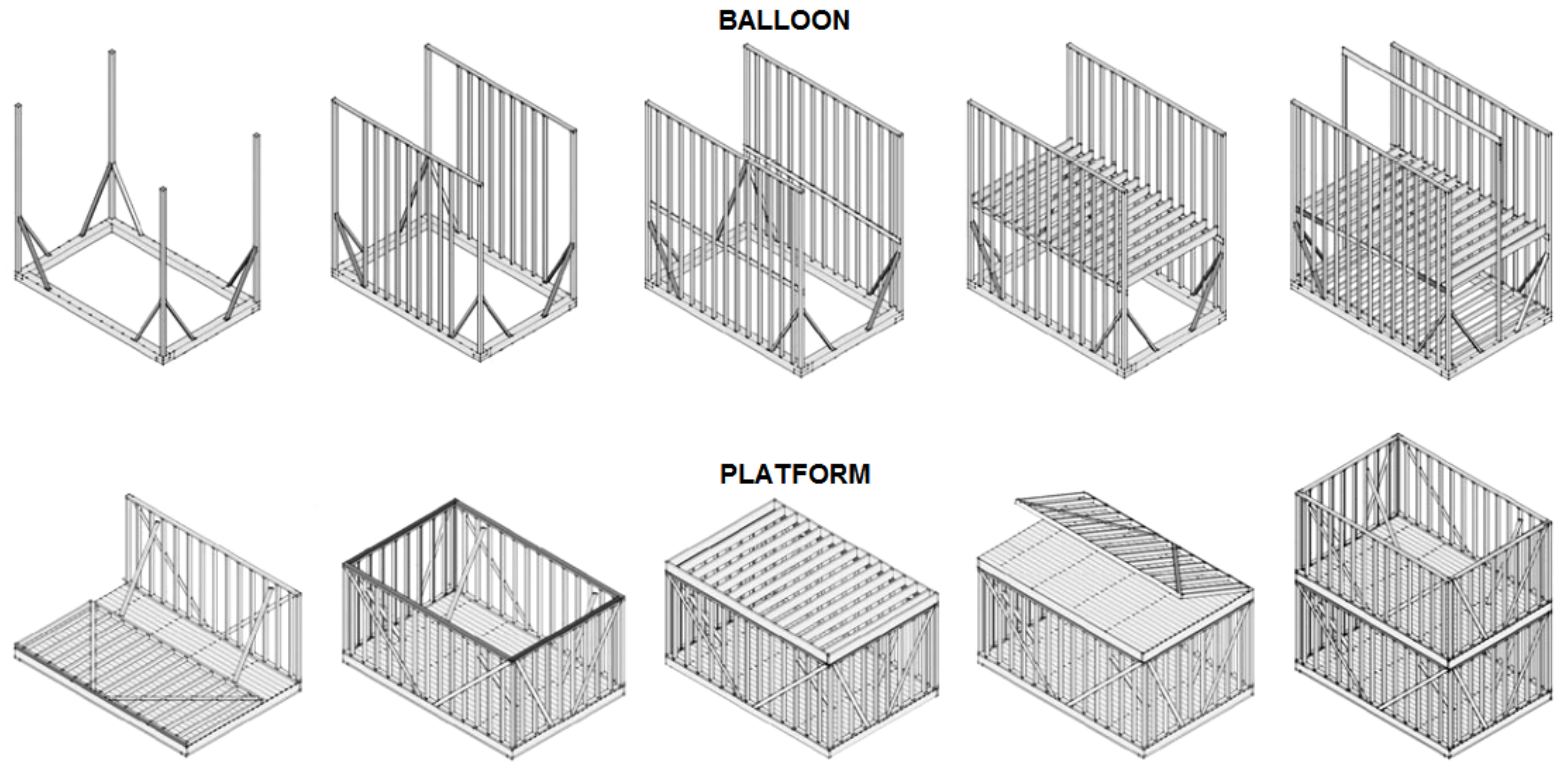

Despite its unpopularity, Ching (2010) states that minimum retraction of the balloon system elements makes it an interesting alternative to walls covered with exposed bricks or plaster. Idealized from balloon framing, the platform frame was created in 1850, through three- dimensional walls, modulated and assembled with small and very light lumber parts, easily worked by one or two workers, generating a versatility in the preparation and assembling of the 
building (O'Brien, 2010). In platform frame, first floor joists are completely covered with sub-flooring to form a platform upon which exterior walls and interior partitions are erected (American Wood Council, 2001).

Gómez et al. (2003) reflect that platform is a lightweight wood structure characterized by the fact that vertical diaphragms or frames form bearing walls of only a tall floor. Benoit et al. (2008) reveal that frame studs are spaced 40 to $60 \mathrm{~cm}$ and fixed to lower and upper beams by nailing, via pneumatic nailer. Platform is the most versatile of all building systems, because of it is easily and swiftly built with a least investment in tools (Allen and lano, 2009). It is the most popular method due to its simplicity (Durán, 2004). The floor platform is completed at each level (Figure 1), and the walls bear upon the platform rather than directly upon the walls of the storey below (Allen et al., 2009).

The horizontal platforms (floors) are arranged such that they coincide, in general, with the studs modulation of first floor (walls) creating an interrelated structure (Durán, 2004). Latent differences between balloon type and platform woodframes refer to framing type, assembly structure mode, length of the lumber used, and propagation of the loads and fire. Woodframe wall skins have variants that are independent of structural framing (balloon or platform). The sealing is like a "sandwich" of some materials. Figure 2 (left) shows main subsystems of a conventional woodframe:
A. Roofing (infrastructure);
B. Structure (superstructure);
C. Flooring;
D. Foundation;
E. Wall (internal and external walls).

The subsystem which distinguishes the light woodframe from other timber techniques is the wall (internal and internal), named by "E", due to its structural composition and applied elements. Figure 2 (right) shows the elements of a structural wall, which are enumerated by:
1. Plaster board (drywall panel);
2. Framing (studs and plates);
3. Oriented strand board (OSB panel);
4. Vapor barrier and insulation blankets;
5. Wooden lathes;
6. Siding (wall cladding) in wood, vinyl, aluminum, cement, masonry, etc.

Cladding skins could be different, either the amount or type of structural panel. The panel composition can be single (outside as in Fig. 2 right) or double (inside and outside panels " 3 " fixed in the framing " 2 ").

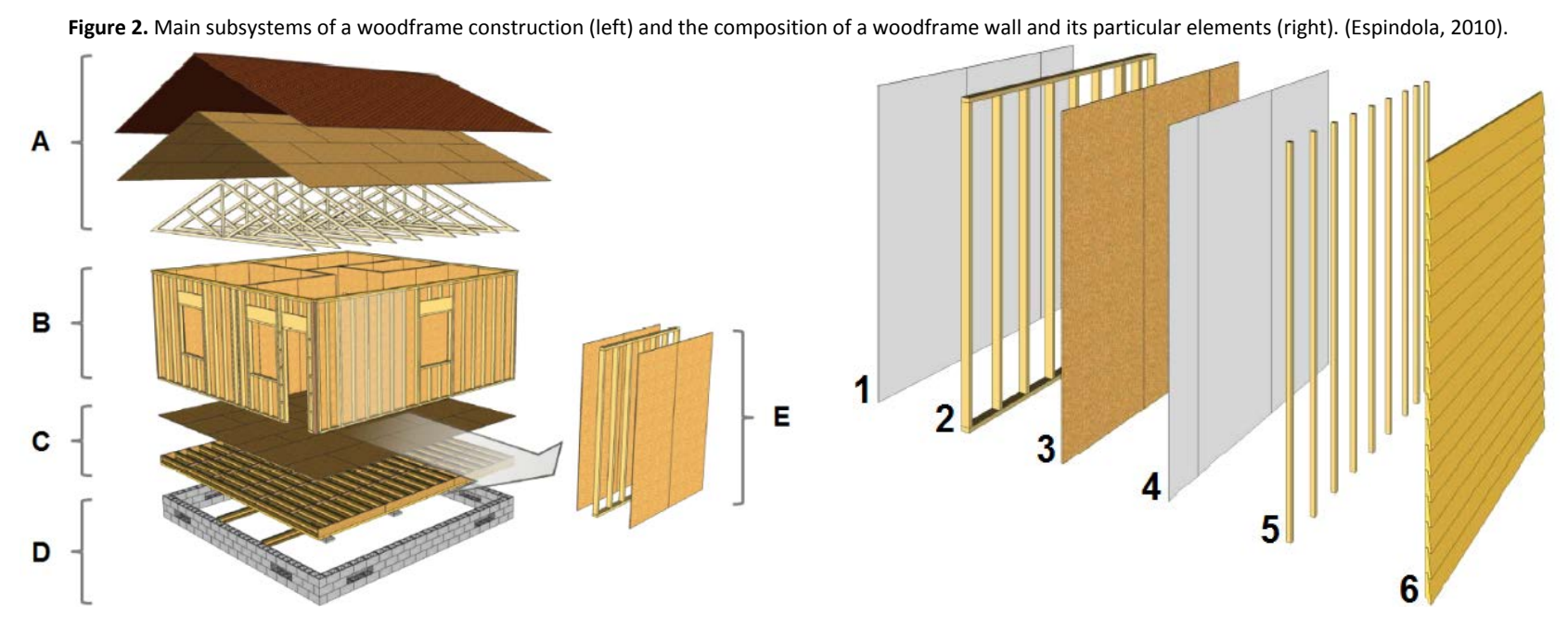

Plywood or OSB could be replaced by fiber-cement or wood-cement panels, especially for non-bearing walls with low structural loads. Architectural versatility of woodframe can be seen in its styles: traditional or contemporary designs (Photo 1); the houses of Photo 1 were built by Shintech in Sorocaba (SP), Brazil. Economic classes can influence the housing finishing quality, from upper to lower classes. Luxury house is a superior option, whereas it is costly due to finest details and ornaments. Photo 2 shows a luxury house built in a gated community at Nova Lima (MG), Brazil; the production of this luxury house was the result of a partnership between two companies: VC Construtora and Stamade. 
Popular houses are compact and simpler, which are destined to lower people. A partnership between Tetti and Stamade resulted in a popular wood framing house built at Itapeva (SP), Brazil (Photo 3).
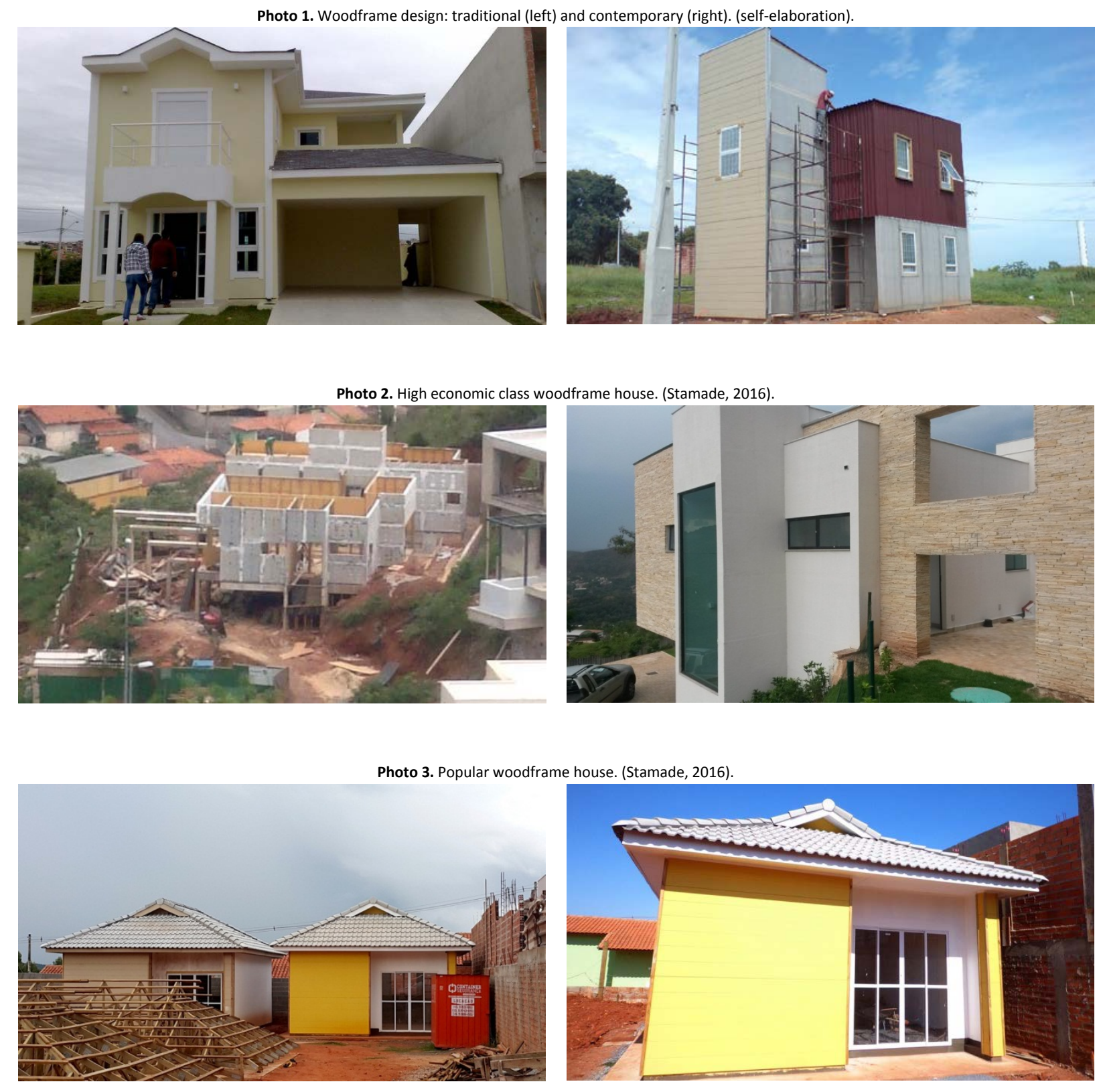

Advantages of the Woodframes

Durán (2004) verifies the major advantage of platform frame enables that each floor can be built independently, since the system provides a platform or work surface, which wall and floor structures are assembled and fixed. Woodframe production is flexible, because it can be industrially produced in large scale or limited customized handmade housing.

Regarding water consumption, the woodframe is classified as a dry construction technology, which provides a significant advantage over other techniques, considering water shortage in urban centers. Due to standardization of the elements/parts prefabrication of a woodframe (usually compact), the ease of organization on site, and the construction cleaning favorably contribute to reduce or eliminate its waste.

Dry construction is erected in a third of total time spent to a conventional masonry, as well as woodframe demands $75 \%$ lower scale of hand labor, generating $25 \%$ less waste than this regular site in masonry (Franco, 2014). There are many reasons why this system has been the choice of professional and amateur builders alike over the years. A main 
reason is its flexibility. Because the modules are small, virtually any shape or style of building can be built easily with the studs, joists, and rafters that are the primary components of wood frame construction (Thallon, 2008).

The standardization of construction elements also contributes to a higher house production speed, both in series as handmade. In addition, the pieces are easily handled, the material is readily available, and the skills and tools required for assembly are easily acquired (Thallon, 2008). Thermal efficiency of the sandwich walls also influences in the complete elimination of the artificial heating system. Together, all these differences can provide favorable attributes related to sustainability of this modern wooden typology. Over time, the woodframe platform became highly popular among most developed nations worldwide.

\section{Brazilian Overview of Wooden Housing}

Zani (2003) emphasizes that, in the late 19th Century, the strong occupation in the South and Center-South of Paraná state occurred by: Pine buildings (Araucaria angustifolia); log-homes of Polish origin; Polish housing with towering roofs, attics and lambrequin eaves; houses in Peroba (Aspidosperma polyneuron) rich in volume and with stately roofs. In the case of the buildings in Araucaria wood became popular through residences with walls of board and batten - similar to wainscoting. They are present in some remaining examples in the Brazilian Southeast and South regions.

The occurrence of these secular wooden board and batten houses throughout the Paraná state reveals an architectural culture, which it was not temporary and or transitory, because it served as shelter for the population for many decades, and it also continues to serve in some cases, but it is slowly disappearing by the constant demolition (Zani, 2003). Despite of Brazil keeps ancient architectural examples of wooden housing, however, the single-family homes in this material is scarce, even from the 1970s, following a notorious decline of these wooden craftedtechniques.

Even with the slow industrialization of the wood sector in Brazil, occurred in middle of the 20th Century, several sawmills and timber companies focused on the production of a lumber-based prefabricated housing typology. This technique of horizontal timber plank - or embedded lumber board - became popular between 1970 and 1990, due to its destination as resting houses or paradise houses such as: beach houses, cottages, chalets, etc. Thus, the leading companies specialized in this specific technique were Casema, Battistella, Condor, Madezzatti, Gramarcos, Kürten, Humaitá, etc. In spite of the thermal-acoustic efficiency, structural strength and remarkable style, these houses of horizontal timber planks still have a strong demand for native lumber, resulting in a more costly and less rationalized technique.

In the search for the utilization of wood from planted forests and a better rationalization of these natural materials in construction, many of the most developed countries have sought by more practical, profitable, and sustainable examples of wooden houses. Generally, timber typologies present a natural evolution, because even the oldest techniques are distinguished by their compact size and simplicity. It could also be confirmed through the influence of German colonization in Latin American nations (Prado, D’Alençon \& Kramm, 2011).

Thus, the woodframe technique emerged as a competitive alternative, occupying interesting requirements and combining advantages of production flexibility, lower production and assembly times, use of reforested wood and wooden panels, practicality in future retrofits, standardization of elements and components, lower expenses with hand labor, simplifying of production stages, etc. For these and other reasons, woodframe became the most popular technique in United States, Canada, Germany, Australia, Scandinavia, United Kingdom etc.

For decades, in many developed nations with higher per capita incoming, and recently, in developing countries such as Chile, building systems based on wood or metal elements and covered externally with wooden structural boards have been massively chosen as a good residential alternative (Lignum, 2013). Contrary to this worldwide movement, the pioneering initiative of building a woodframe house in Brazil was delayed. It only occurred through two basic prototypes. According to Abbate (2002), the first woodframe was built as prototype in 1973 by Gypsum do Nordeste, exploring the use of plaster, its main product.

The second latter example was only built in 2001 by the American builder and woodframe specialist Alfred Lee Edgar, under technical responsibility of the Brazilian civil engineer Carlos Alves. This woodframe is still located in the Cantegril Condominium at the Viamão (RS), Brazil. Months after this timely initiative, the timber company Battistella Indústria e Comércio and construction company Malacon - both located in Paraná state - were the first manufacturers of woodframe housing in Brazil. Over time in Brazil, wooden framing housing attracted more attention 
from the local timber sector. In short, this timber chain gained a larger portfolio of companies, also including to some producers from other wood housing techniques with lower levels of material use.

Nevertheless, Brazil is experiencing a very different moment in construction, because of the new building techniques, recent advanced production technologies, and innovative raw materials and products; altogether, these facts have enabled the proliferation of sustainable residential examples, with higher levels of raw material rationalization. The current greatest example resulted in the realization of Residential Haragano, located in Pelotas (RS), Brazil. It was built during mid-2012 and completed in early 2013. According to Ferreira (2013), that consisted of the first Brazilian enterprise for woodframe housing, exclusively for "Minha Casa Minha Vida" dwelling program, by a partnership between Roberto Ferreira (construction company) and Tecverde (woodframe kits producer). About 280 units of $45 \mathrm{~m} 2$ were produced for the project: 270 two-storey houses, and 10 single-storey units (Ferreira, 2013; Franco, 2014).

According to Franco (2014), through these kits in woodframe of Tecverde, other popular housing projects are being promoted in state of Paraná, through three partnerships among Tecverde and two construction companies: F-Klaas to build 67 houses in Curitiba; and Bau Construtora to build 250 units in São Miguel do Iguaçu and to build other 23 in Rio Bom. These three cities are located in Paraná, which currently is the most advanced Brazilian state in wooden housing. For the realization of these residential projects and the possibility of obtaining financing for the low income people, through a Brazilian public financial institute (Caixa Econômica Federal), several barriers had to be overcome.

Ferreira (2013) also notes that the woodframe system necessarily needs to be submitted to many tests, proving its compliance - in tests of mechanical resistance of structural parts, acoustic, thermal, and fire resistance - with the guidelines and prescriptions of the SINAT (National System of Technical Evaluation of Innovative Products) deliberated by Ministry of Cities of the Brazilian government. Even with the existence of some still negative cultural barriers on the wood houses in Brazil, currently some public agencies have helped - even if occasionally - and also stimulated the production of other building technologies that can integrate the list of residential techniques, today strongly dominated by masonry.

As the example of several North American and European countries and Chile, the timber houses are reaching an important space, with brick masonry and other building techniques, because of its advantages, especially related to the industrialization at higher levels. Today in Brazil the situation is becoming a booming. Brazil possesses in 2016 about 22 woodframe manufacturers by artisanal, industrial lines or project office with execution under a partner's responsibility. Moreover, two companies will produce wood framing houses at Paraná state in the future, insofar as they are producing (or have produced) woodframe prototypes.

Concomitantly, three companies are in study phase for a future implementation to produce woodframe at São Paulo state. In the two new cases, platform frame was the selected option. Table 1 mentions the Brazilian manufacturers specialized in woodframes. It can be verified that $41 \%$ of these companies (9) are at the São Paulo state (SP), probably because this region possesses the major consumer market, and it concentrates the second largest planted forest area in Brazil. Reinforcing their timber-forest vocations, the states of Paraná (PR), Santa Catarina (SC), and Minas Gerais (MG) have four, three, and two companies, respectively. In this scenario, the woodframe future can be promising in Brazil.

Table 1. List of Brazilian woodframe manufacturers. (self-elaboration).

\begin{tabular}{|c|c|c|}
\hline Companies & Production Focus & Brazilian Cities / States \\
\hline Stamade & Projects and Execution Office & São Carlos / SP \\
\hline Shintech & Artisanal Producer & Sorocaba / SP \\
\hline Abitare / Tetti & Industrial Producer & Capão Bonito / SP \\
\hline Madeframe - Construframe & Artisanal Producer & Vargem Grande Paulista / SP \\
\hline Carpinteria Estruturas de Madeira & Projects and Execution Office & São Paulo / SP \\
\hline RBA Eco Home & Artisanal Producer & São Paulo / SP \\
\hline Buselli Arquitetura & Projects and Execution Office & Limeira / SP \\
\hline KWF Construções Sustentáveis & Artisanal Producer & Avaré / SP \\
\hline Caribea - Casa Inteligente & Industrial Producer & São Manuel / SP \\
\hline Ecos Haus / Grupo Kürten & Industrial Producer & Curitiba / PR \\
\hline Tecverde & Industrial Producer & Curitiba / PR \\
\hline Volver Sistemas Construtivos & Artisanal Producer & Curitiba / PR \\
\hline Casa Rápida Curitiba & Artisanal Producer & Curitiba / PR \\
\hline Montaggio Wood\&Steelframe & Artisanal Producer & Cascavel / PR \\
\hline Durigon Homes & Artisanal Producer & Joinville / SC \\
\hline Holz Haus & Artisanal Producer & Florianópolis / SC \\
\hline Bolsoni Carpintaria & Artisanal Producer & Florianópolis / SC \\
\hline Madeiras MG & Artisanal Producer & Belo Horizonte / MG \\
\hline
\end{tabular}




\begin{tabular}{ccc}
\hline Elemental Construtora & Projects and Execution Office & Uberlândia / MG \\
\hline Roberto Ferreira Construções & Projects and Execution Office & Porto Alegre / RS \\
\hline Surya Frame Engenharia & Artisanal Producer & Rio de Janeiro / RJ \\
\hline Casa Certa & Artisanal Producer & Brasília / DF \\
\hline Embafort Sistemas Construtivos & Future Industrial Producer & Curitiba / PR \\
\hline Immergrün (Grupo Lenz / Berneck) & Future Industrial Producer & Balsa Nova / PR \\
\hline TaqPinus & Study Phase (Industrial Producer) & Taquarivaí / SP \\
\hline Solução Madeiras & Study Phase (Industrial Producer) & Arujá / SP \\
\hline Canteiro Construções Racionalizadas & Study Phase (Industrial Producer) & Santa Isabel / SP \\
\hline
\end{tabular}

\section{Integrated Actions about Wood Framing in Education, Research and Community}

Research on structures and wooden houses in Brazil were initiated more than 30 years ago in Laboratory of Wood and Timber Structures (LaMEM) and Research Group on Housing \& Sustainability (Habis), both from University of São Paulo (USP) at São Carlos. Years later, these studies were performed by the Center Oriented for Building Innovation (NORIE) of the Federal University of Rio Grande do Sul (UFRGS) at Porto Alegre, and by Group of Housing Studies (GHab) and Interdisciplinary Group on Wood Studies (GIEM), both from Federal University of Santa Catarina (UFSC) at Florianopolis. Later, timber structures and housing studies also succeeded in the Faculty of Architecture and Urbanism (FAU) from the University of Brasilia (UnB) at Brasília.

In general, these initiatives were associated to Civil and Structural Engineering, Architecture and Urbanism and Forest Engineering. By the creation of the modern course in Wood Industrial Engineering and its implantation in Brazil, the wood industrialization for housing had its wider focus. This avant-garde course started in the Federal University of Paraná (UFPR) in 1998 at Curitiba, and at the same time, this course was installed at the Campus of Itapeva from São Paulo State University (UNESP) in 2003. The course is also present in Federal University of Pelotas (UFPel), and Federal University of Espírito Santo (UFES).

Over the past decade, the academic purpose of studies and research targeted in wood housing was retaken by actions realized at UNESP-Itapeva, particularly about woodframe topic. An extension course named "Education in Wood" was created in 2007 for wood framing dissemination as a modern housing alternative in Brazil. Two woodframe classrooms were built to serve as a building model (Photo 4). Over time, this pioneering spirit demonstrated by the idealization of the model-rooms was expanded, in several actions realized at the UNESP-Itapeva, through some pilotprojects and developments of products and composites aiming to nationalize foreign building parts and components for housing.
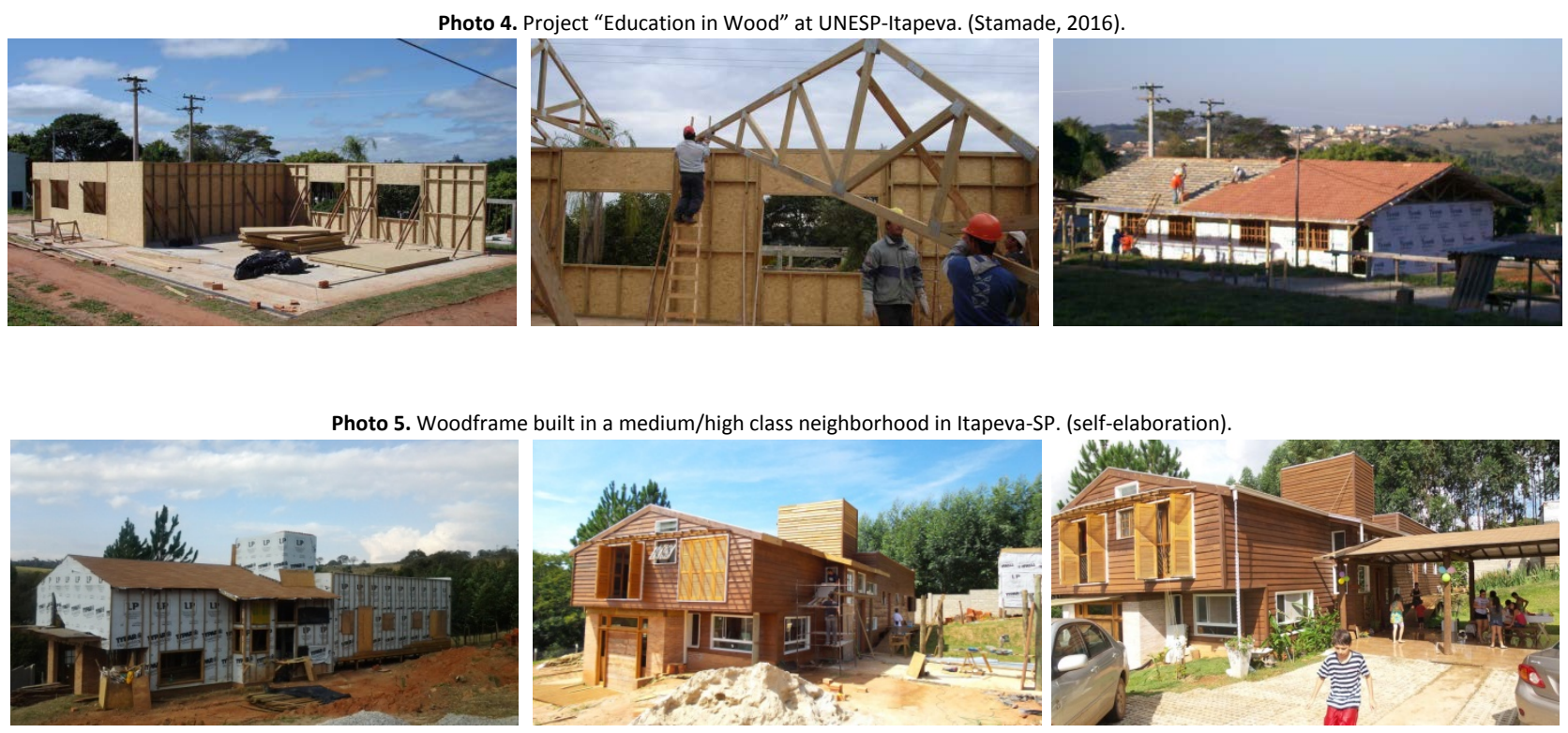

New thermo-acoustic insulation for framing, waterproofing covering, composites based on bamboo and timber, and reinforced structural elements for woodframe have been developed and patented for UNESP-Itapeva, which have been performed by teachers, researchers, and students at Research Group of Development of Lignocellulosic Products (LIGNO). 
In these activities, a woodframe housing unit was built in artisanal scale, at Itapeva, Brazil. Photo 5 shows its building process. It included the student involvement of the Wood Industrial Engineering of UNESP-Itapeva in order to disseminate the woodframe for local people and entrepreneurs. This strategy will serve as an inducer channel to unmask the old negative label about timber housing. In wood framing popularization context, the Research Group LIGNO has headed a new community project - called "Dona Amélia" - which aims to meet, through a participatory and collective action, the artisanal production at the UNESP of some popular woodframe for poor people and breadwinner women. This process will involve wood industrial engineering students, as well as local companies, professionals, and government officials.

\section{Strategies to Woodframe Diffusion}

Initially, an important strategy for the full dissemination of woodframe in Brazil and or in developing countries is concentrated in the continuation of the academic studies realized by many actors of the courses directly related to wooden buildings and structures. This local stimulus could cover the suitable adaptation of the materials and innovative techniques in wood in these countries with difficulties in housing shortage.

In parallel, the proliferation of other model-projects to popularize the woodframe housing should approximate it to the consumers and the industry surrounding the research centers and the universities focused on this strategy. The detailed divulgation of this technique in events (fairs, congresses, symposia, seminars, workshops and meetings), exploring the main advantages and applications, it will also serve as a mark to expanding the knowledge, and consequently, to increase the number of new houses manufactured in light woodframe.

The use of woodframe in new popular single-family housing by government of countries in Latin America would facilitate its expansion and penetration in needy people class. This fact would expand the market for all the companies in timber production chain, i.e., manufacturers to raw material suppliers. This situation was implemented in Brazil in 2013, by the creation of the aforementioned neighborhood "Residencial Haragano", entire in woodframe, through a still timely initiative of the Federal program "Minha Casa Minha Vida" for people without home.

An important detail to be explored in this fact could be the better elucidation of woodframe competitive costs. Franco (2014) emphasizes that a single-family residence among 43 to $50 \mathrm{~m} 2$ in the standards of the program "Minha Casa Minha Vida" has a cost lower than US\$12,000 in woodframe technique, and around US\$21,000 for a similar house in masonry. This cost difference between these techniques provides a great future possibility for a large-scale industrialization of the woodframes.

Production flexibility showed by woodframes should be another aspect to be clarified. In the two production types (artisanal and industrial) this technique achieves a high efficiency, due to the lower levels of timber consumption, manufacture time and waste generation. No-water use and the construction cleaning are other attributes to be heavily explored. However, accurate woodframe popularization must be made effectively, in particular by the exploration of the use of these residences for local artists and renowned celebrities. A good example of this fact is being explored by the Brazilian woodframe manufacturer Elemental Construtora, which has explored higher class woodframe houses particularly produced for three renowned Brazilian backcountry artists. Similar strategy with more celebrities would further the woodframe diffusion.

Finally, a larger disclosure appeal of wooden framing housing in print, digital and broadcast media, possibly realized by construction and timber associations, or else by the woodframe manufacturers, this could also be an important channel for dissemination and information of the qualities, benefits and options offered by these sustainable typologies. Therefore, the realization of these practices would contribute immediately to the wooden framing consolidation as an interesting house alternative in developing countries from Latin America such as Brazil, Argentina, Colombia, Uruguay, Chile, and Mexico, as well as from other regions as Russia, South Africa, Angola, India, China, Singapore, etc.

Stamato and Oliveira Junior (2008) stated that is notorious that the cultural inertia obstructs the market growth of wooden buildings. This negative barrier is linked to the depreciation by the people, who do not know its qualities and advantages before the masonry. The high level of raw material rationalization of woodframe positions prominently ahead other wood building typologies, which in general, they consume larger lumber amounts. The recent globalization has contributed to the diffusion of better inputs for woodframes. 
This fact has facilitated the import of inputs, thitherto rare or nonexistent in most of the developing countries. It also has provided the national manufacturing of many raw materials and accessories specifically designated for this wooden building technique. Therefore, the possibility of the high level of woodframe industrialization allows that new companies - focused on the manufacturing of these inputs suitable for this technique - can be installed throughout the Latin American market. Lastly, the massive participation and action of the universities and their research groups for the development of products and processes to woodframes, concomitantly with the effective implantation of the aforementioned strategies for their popularization, altogether, they will have great importance for this wood typology. It will allow that it can compete in this uneven housing market, which it is widely dominated, in most of Latin countries, by the stronger industries of steel, cement and aluminum, i.e., because of the monstrous proliferation of the techniques in masonry of bricks and concrete.

References

Abbate, V. (2002). Do bloco ao painel. Techne, 35-39.

Allen, E., \& lano, J. (2009). Fundamentals of building construction: materials and methods (5th ed.). Hoboken (NJ): John Wiley.

Anderson, L. O. (1975). Wood-Frame House Construction. Washington (DC): U.S. Department of agriculture.

Benoit, Y., \& Paradis, T. (2008). Construction de maisons a ossature bois (4th ed.). Paris: Eyrolles/FCBA.

Ching, F. K. (2010). Tecnicas de construcao ilustradas (4th ed.). Porto Alegre: Brookman.

Cortez-Barbosa, J., Silva, J. R. M. da, Alvarenga, F. de, Souza, A. J. D. de, De Araujo, V. A., \& Garcia, J. N. (2014). Simulation Analysis of In-Service Bamboo and Pine EGP Composite Flooring. Advanced Materials Research, 1025-1026(2014), $233-240$. http://doi.org/10.4028/www.scientific.net/AMR.1025-1026.233

Council, A. W. (2001). Details for conventional wood frame construction. Washington (DC).

Durán, A. F. (2004). La construcción de viviendas en madera. Santiago, Chile: Corporación Chilena de la Madera. 643 p.

Espindola, L. da R. (2010). Habitacao de Interesse Social em Madeira Conforme os Principios de Coordenacao Modular e Conectividade (p. 147).

Falk, R. H. (2010). Wood as a sustainable building material. In F. P. Laboratory (Ed.), Wood as an Engineering Material (Centennial, pp. 1-6). Madison (WI): Forest Products Laboratory.

Ferreira, R. (2013). MCMV da madeira: conheca a tecnologia e os custos de construcao do primeiro empreendimento em wood frame do programa minha casa minha vida. Guia Da Construcao, 16-25.

Forest Products Laboratory. (2010). Wood Handbook: Wood as an Engineering Material (Centennial). Madison (WI): Forest Products Laboratory. http://doi.org/General Technical Report FPL-GTR-190

Franco, A. P. (2014, July 12) Habitação diversifica métodos de construção. Gazeta do Povo. Curitiba, PR, Brazil. Retrieved from: www.gazetadopovo.com.br/economia/conteudo.phtm!?id=1483426\&tit=Habitacao-diversifica--metodos-de-construcao

Gomez L., L., Leser S., H., \& Salomone R., V. (2010). El sistema constructivo plataforma (plataform frame) en Sewell. Revista de Urbanismo, Junio 2003(8), 145-158. http://doi.org/10.5354/0717-5051.2003.5071

Junior, C. C., \& Dias, e A. A. (1997). Utilizacao da madeira em construcoes rurais. Agriambi, 1, 71-77.

Kruger, E. L., \& Laroca, C. (2009). Avaliacao de desempenho termico de prototipo de baixo custo em madeira de reflorestamento. Rem: Revista Escola de Minas, 62(4), 447-454. http://doi.org/10.1590/50370-44672009000400006

Lignum. (2013). Construcción en madera: la opción eficiente. Lignum: Bosque Madera and Tecnología, 76-76.

O'Brien, M. J. (2010). Hybrids on the way to the Western Platform Frame. In Preservation Education \& Research (Ed.), Preservation Education and Research (Vol. Four, pp. 37-52). New York: NCPE.

Pfeil, Walter; Pfeil, M. (2003). Estruturas de Madeira (6th ed.). Rio de Janeiro: LTC.

Prado, F., D’Alençon, R., \& Kramm, F. (2011). Arquitectura alemana en el sur de Chile: Importación y desarrollo de patrones tipológicos, espaciales y constructivos. Revista de La Construcción, 10(2), 104-121. http://doi.org/10.4067/S0718-915X2011000200010

Stamato, G. C. (2016). Stamade. Retrieved from http://stamade.com.br/

Stamato, G. C., \& Oliveira Junior, A. C. (2008). Projeto Educacao em Madeira. In 11th Encontro Brasileiro em Madeira e Estruturas de Madeira (pp. 1-15). Londrina: Ibramem.

Szücs, C. P. (2006). Sistema STELLA/UFSC: avaliacao e desenvolvimento de sistema construtivo em madeira de reflorestamento voltado para programas de habitacao social. In Bonin, L. C. \& de Amorim, S. R. L. (Eds.), Inovacao Tecnologica na Construcao Habitacional (Vol. 6, pp. 66115). Porto Alegre: Antac.

Thallon, R. (2008). Graphic guide to frame construction. Newtown (CT): Taunton Press.

Wacker, J. P. (2010). Use of wood in buildings and bridges. In F. P. Laboratory (Ed.), Wood as an Engineering Material (Centennial, pp. 1-13). Madison (WI): Forest Products Laboratory.

Zani, A. C. (2003). Arquitetura em madeira. Londrina: Eduel. 